\title{
Humanitarian logistics at a Crossroads: \\ How logisticians reconcile their professional and humanitarian identities in response to tougher host government regulations $\uparrow$
}

\section{$\dagger$ Author accepted manuscript}

Nonhlanhla Dube* (‥dube@lancaster.ac.uk), Manda Broekhuis** (h.broekhuis@,rug.nl)

* Department of Management Science, Lancaster University, Lancaster, United Kingdom

**Department of Operations, University of Groningen, Groningen, The Netherlands

\begin{abstract}
Humanitarian aid workers increasingly experience pressure to professionalise their services in order to ensure more efficient and effective assistance to disaster victims. Particularly for logisticians, this pressure is also the result of increasingly tough regulations imposed by host governments. This causes a dilemma for aid workers: professionalisation can be at odds with their humanitarian values and principles, such as providing unhindered assistance, without discrimination, to whoever needs it. This research explores how humanitarian logisticians experience and deal with this dilemma. In particular, how they reconcile humanitarian values and principles on the one hand with their (developing) professional standards and practices on the other. Theoretical concepts on professionalisation, social identity and so-called boundary work are used to analyse the problem. Results show that individual logisticians adopt one of four distinct identities when approaching reconciliation, namely: professionaldominance, intersection, union or humanitarian-dominance identities. The associated approaches inform how they engage with stakeholders and make decisions. Each approach has its benefits and shortcomings in various operational settings. This implies there is a need to further establish the settings in which each approach delivers the best logistics performance.
\end{abstract}




\section{Introduction}

The professionalisation of humanitarian work is increasingly needed to ensure timely and reliable provision of assistance to disaster victims in complex operating environments characterised by a growing scale and scope of needs (Barnett, 2013; Moore and Taylor, 2011; Kunz and Reiner, 2012; Thomas and Kopczack, 2005; Walker and Russ, 2010). Indeed, the humanitarian sector is evolving from an impromptu, emotion-driven system to a professional service delivery system as evidenced by the establishment of professional functions (Walker et al., 2010). While members of a profession tend to become more similar in terms of norms, values and practices over time, the humanitarian identity is multifaceted, constantly renegotiated and takes on different meanings for individuals over time (Barnett and Weiss, 2008; Duffield 2007; Pache and Santos, 2010; Weiss, 1999). As a consequence, the professional identity of any specific function needs to be constructed against a divergent and fluid humanitarian identity. This implies that competing objectives and conflicting value systems will have to be reconciled in a context with multiple institutional pressures (e.g., Pache and Santos, 2010; Walker, 2004; Zotova et al., 2014). Our research aims to shed light on how humanitarian workers experience and deal with this need to reconcile their professional and humanitarian identities in a complex empirical context; an issue that is scarcely addressed in the literature despite its potential to hamper the professionalisation of humanitarian work.

The humanitarian logistics function exemplifies the challenge of reconciling the professional and humanitarian identities. In addition to the drive for timely and reliable service delivery, professionalisation is pushed through increasing host government requirements that logisticians work according to specified standards and regulations (Abbey, 2008; Day et al., 2012). Such regulations can facilitate good logistics performance by, for example, establishing clear lines of command in disaster response, limiting the influx of unsolicited donations and regulating the activities of organisations that might cause disruptions (Day et al., 2012; Dube at al., 2016; Holguín-Veras et al., 2012; Kunz and Gold, 2017; Smith, 2011; Welling et al., 2010). However, host governments can also use similar strict regulations to hinder the humanitarian imperative to provide impartial assistance to vulnerable populations. For example, they may restrict travel to areas with marginalised population groups (Dube et al., 2016; Kunz and Reiner, 2016).

In this research, we explore the following research question: "How do humanitarian logisticians reconcile their humanitarian identities (which can be divergent and fluid) with their developing professional identity (which tends to converge and become more stable over time)?" Related, we seek a basic understanding of the implications of this for the timely and reliable delivery of supplies across operational settings.

In line with our recognition that an individual's humanitarian and professional identities are socially constructed based on one's points of view, an interpretive case study approach is adopted (Cavana et al., 2001; Geertz, 1973). This approach leads to in-depth insights into "the complex world of lived experience" from the perspective of those living it (Schwandt, 1994, p. 118). We specifically focus on humanitarian logisticians working for a Dunantist 
organisation because of its unparalleled insistence on the preservation of its humanitarian identity (Barnett, 2005) - whatever that may mean to different individuals - while at the same time seeing providing timely assistance to disaster victims as paramount.

The main contribution of this research is in generating insights into the underlying identity issues that shape and inform the development of humanitarian professions. In particular, we take a different perspective from existing research on the professionalisation of humanitarian logistics which has so far largely focused on personnel training and skills (e.g., Allen et al., 2013; Kovács et al., 2012), by exploring how individual logisticians reconcile their humanitarian and professional identities. Our findings show that individuals have different ways of coping, implying the need to consider the fitness of individuals for an operational setting in which they are posted. Our work could also be useful for understanding professionalisation in other transnational professions where high levels of performance are required but stark identity differences (such as cultural and national identities) exist across operational settings.

The rest of the paper is organised as follows. Section 2 outlines the theoretical background of the research. The research methodology is presented in Section 3 followed by a presentation of the results in Section 4. A discussion and conclusions follow in Section 5.

\section{Theoretical background}

\section{Two social identities: the humanitarian identity and the professional identity}

In this research, two social identities are considered: the humanitarian identity and the professional identity. Social identity is "that part of an individual's self-concept which derives from his knowledge of his membership in a social group (or groups) together with the value and emotional significance attached to that membership" (Tajfel, 1982 in: Jussim et al., 2001, p. 6). Social identity is constructed as individuals engage in social interaction and social contexts (Operariro and Fiske, 1999; Tajfel, 1982). Individuals choose their social identities from bases of self-categorisation available to them at a given time (Brewer, 2001). As such, social identity is malleable, individuals hold multiple shifting and hierarchically organised social sub-identities (Hotho, 2008).

The humanitarian identity largely relates to universal humanitarian values, beliefs and norms. These include not taking sides when offering humanitarian assistance in conflict situations (i.e., neutrality); providing humanitarian assistance without discrimination, such as based on nationality, race, religion or political affiliation (i.e., impartiality); moral and ethical conduct; and accountability (Minear and Weiss, 1993, in: Hilhorst, 2002; Leader, 2000). Although all humanitarian subgroups/organisations share a humanitarian identity, they interpret it differently (Stoddard, 2003; Weiss, 1999). Even within an organisation, there are differences in individuals' interpretations of what constitutes a humanitarian identity (Barnett and Synder, 2008; Barnett and Weiss, 2008; Weiss, 1999). 
Professional identity generally refers to membership of an occupational group with a dominant position in a division of labour (Freidson, 1970) based on a knowledge field. As such, professionalisation is a process that entails renegotiating often disputed and historically determined boundaries of responsibility and expertise between different professional and occupational groups (Grbic, 2010). Professionals take autonomous decisions within their domain and often develop a self-regulating system of governing standards, norms and values (Abbott, 1981). These standards reflect the ideas that an individual or a group has about how to perform a job within their professional domain. Professional identity, however, can have a variety of meanings in various settings (e.g., Beijaard et al., 2004).

Within the humanitarian sector, the "humanitarian professional" is recognised as an individual who practices an existing profession (e.g., an engineer, accountant, epidemiologist or nutritionist) within a disaster environment and is able to adapt and respond to arising situations in a calm, clear-headed and intuitive manner (Walker and Russ, 2010, 2011). In other words, a professional humanitarian tends to be an individual with a well-established professional identity who applies their skills in a humanitarian setting where other skills are also needed for adaptability and swift action in often chaotic and dangerous situations. Humanitarian logisticians, on the contrary, tend to be individuals who are highly adaptable and quick to action in a disaster environment but lack the professional skills or training needed to fill a general logistics function (Kovács et al., 2012; Tatham and Pettit, 2010). Therefore, they have a highly developed humanitarian identity, as a result of exposure to the humanitarian setting, but are still on the path to professionalisation.

\section{The logistician's challenges in reconciling the two identities}

Government regulations can contribute to the professionalisation of logistics in one of two ways. First, this can be through the direct support and recognition of certain functions as professions. In Burkina Faso, for example, the legitimacy of the health logistician as a profession has been accelerated by regulatory adjustments that facilitated the creation and incorporation of this function into the healthcare system (Silve and Ouedraogo, 2013). This coupling of the profession with certain legal provisions was in recognition of the fact that efforts to improve healthcare access in developing countries are often undermined by poor logistics expertise and dubious practices (Silve and Oedraogo, 2013). Second, governments can use regulations to push for positive change in specific industries, thereby initiating the development of certain skills and capabilities of the professionals therein. For example, the growing concerns about global warming have triggered regulations intended to reduce polluting logistics activities (Dey et al., 2011; Lin and Ho, 2011). In turn, organisations have responded through compliance and/or proactive adjustments before new regulatory implementation to ensure good logistics performance (Barker and Zabinsky, 2010; Tyler et al., 2008). These responses may require additional training to increase knowledge of the prevailing regulations and how to comply with them and, here, professional certification organisations can play a significant role (e.g., Pohlen, 2011).

Government regulations can also be used for political or economic reasons that result in negative consequences for timely and efficient processing, e.g., trade restrictions, customs 
procedures, discriminatory regulations aimed at protectionism and taxation (Hollweg and Wong, 2009; Rahman and $\mathrm{Wu}, 2011)$. Hollweg and Wong (2009) identify 16 restrictions related to customs procedures alone.

In humanitarian operations, organisations increasingly depend on the host governments' permission to assist disaster victims - a largely political issue (De Leeuw, 2010; Seekins, 2009). Furthermore, the push for change in terms of economy and quality control has led to an increase in regulations affecting international procurement and donations by IHOs (Ergun et al., 2009; Holguín-Veras et al., 2012; Kunz and Gold, 2017). Whatever the reasons for a host government's actions, logistics performance is highly dependent on the humanitarian logisticians' ability to comply with local and national government regulations (De Leeuw, 2010; Dube et al., 2016). This hinges on the development of humanitarian logistics as a profession.

The humanitarian identity and the professional identity do not always converge, and this can impose contradictory requirements on an individual. For example, some governments can use regulations to ensure the exclusion of disaster victims in desperate need of assistance (Bratton, 1989), and import restrictions could expose beneficiaries to potentially harmful products (Fernandez et al., 2008).

When individuals are confronted with such differences in their social identities, they make an effort, in defining the social self, to reconcile the competing implications (Roccas and Brewer, 2002). Members within the same occupational group can have differing interpretations of the same phenomenon, such as, in the case of humanitarian logisticians, import restrictions. Consequently, they can have different ways of reconciling the diverging identities and thus can have differing responses to that phenomenon (Grbic, 2010; Roccas and Brewer, 2002). Figure 1 highlights and explains four possible social identity profiles that individuals may adopt when reconciling two identities: intersection, dominance, compartmentalisation and merger (Roccas and Brewer, 2002).

\begin{tabular}{|c|c|c|c|}
\hline INTERSECTION & $\begin{array}{l}\text { Individual assumes simultaneous } \\
\text { recognition of multiple identities by } \\
\text { defining the in-group as the intersection } \\
\text { of multiple group memberships. Here } \\
\text { multiple bases of group identification } \\
\text { are consolidated to one in-group and } \\
\text { converge to a single social identity. }\end{array}$ & DOMINANCE & $\begin{array}{l}\text { Individual adopts one primary group } \\
\text { identity to which all other (potential) } \\
\text { identities are subordinated. The } \\
\text { subordinated identities are } \\
\text { encapsulated within the primary group } \\
\text { identification but are not extended to } \\
\text { those outside the primary group } \\
\text { identification. }\end{array}$ \\
\hline$A$ or $B$ & $\begin{array}{l}\text { TION } \\
\text { Individual assumes multiple identities } \\
\text { which are activated and expressed at } \\
\text { different times depending on the } \\
\text { context/ situation but never } \\
\text { simultaneously. In } \\
\text { compartmentalisation more than one } \\
\text { group identity is important to the } \\
\text { individual. }\end{array}$ & MERGER & $\begin{array}{l}\text { Individual recognises and embraces non- } \\
\text { convergent group memberships } \\
\text { simultaneously. In-group identification } \\
\text { is extended to anyone who shares any of } \\
\text { the recognised social category } \\
\text { memberships. Thus social identity is the } \\
\text { sum of the individual's combined group } \\
\text { identifications. }\end{array}$ \\
\hline
\end{tabular}


While the work of Walker and Russ (2010) suggests dominance of the professional identity, i.e., individuals are professionals first and humanitarians second, others argue that the humanitarian sector has opted for expert authority nested within moral authority, i.e., the humanitarian identity has dominance over professional identity (Barnett, 2013). Notwithstanding this fundamental difference, both scenarios arguably represent situations where an individual does not experience tension between the two identities. However, it is conceivable that individuals may adopt other social identity profiles, as depicted in Figure 1, when they perceive their sub-identities as misaligned. For example, humanitarian logisticians might lack full autonomy in setting the norms, standards and values related to their professional identity because, for example, a host government adopts an uncompromising stance on logistics-related regulations (Dube et al., 2016). Particularly for humanitarian logisticians with Dunantist roots (i.e., whose organisations seek dissociation from government interests) (Stoddard, 2003), their rule-averse nature may mean that they are reluctant to comply with professional logistics norms and standards set by host governments. The desire to serve the disaster victims may force them to find some middle ground in defining the self in the professionalisation process. Thus, humanitarian logisticians might adopt several social identity profiles and this could affect the professionalisation process of the humanitarian logistics function.

\section{The professionalisation process and boundary work}

In addition to dealing with the pressures from host government regulations, humanitarian logisticians also have to deal with potential tensions with other occupational groups in the sector. These groups constitute something like an open ecological system: they are interdependent on one another, are frequently changing and compete for legitimacy (Abbott, 1988). The process of professionalisation is initiated by changes in the context that lead existing and aspiring professions to employ strategies to defend their domain boundaries, make claims to new areas of expertise, or reject attempts to impose these upon them (Coburn, 2005; Nancarrow and Borthwick, 2005). Therefore, boundaries between professional domains are negotiated, historically contingent, and can be disputed as professions develop (Grbic, 2010), on both the national and international levels. This notion is central to the theoretical concept of boundary work, i.e., the processes and strategies that lead to the (re)establishment of boundaries among occupational groups in terms of areas of responsibility and expertise (Anagnostopoulos, 2006; Grbic, 2010; Gieryn, 1999). This theoretical concept refers to the work of Faraj and Yan (2009) who focused on team boundary work, showing that teams, and individual team members, deploy both engaging and disengaging activities to establish and maintain their team boundaries. They have to obtain and secure resources and coordinate their work with their environment: engaging boundary work. They also perform disengaging boundary work by either reinforcing their own boundaries through increasing members' awareness of their specific boundaries relative to the environment (including other occupational groups) or closing off the team from environmental disturbances. 
Although this theoretical concept was not initially included in our study, we discovered inductively that humanitarian logisticians employ a range of boundary activities to protect and define the boundaries of their occupational domain. At this individual level, we define boundary work as all interaction and coordination activities that humanitarian logisticians undertake to establish and maintain their occupational domain. Having added the boundary work aspect to our research process, we went a step further to establish its link with the various social identity types in order to better understand the professionalisation process of humanitarian logisticians.

\section{Research methodology}

\section{Research Approach}

The research design was a single case study investigating how humanitarian logisticians working for a Dunantist international humanitarian organisation (IHO) reconcile their developing professional identity with their humanitarian identity. The exploratory nature of this research and the complexity of the setting warranted the use of the case study design (Stuart et al., 2002). Our aim was to document and interpret the social identity types that these humanitarian logisticians assumed in this process as fully as possible and from their own point of view or frame of reference (Leininger, 1985). Since any tensions experienced and social identities assumed are likely to depend on how individuals make sense of reality, an interpretive approach was adopted.

The investigated IHO provided an excellent setting for this research as Dunantist organisations try to maintain a clear distinction between politics and humanitarianism (Stoddard, 2003). Dunantist organisations try to dissociate themselves from governments, are rule-averse, and see themselves as providing palliative relief pending the development of permanent solutions to the root causes of a humanitarian crisis. Nevertheless, over time, differences in how they interpret and enact this in their operations have developed (Duffield, 2007; Pache and Santos, 2010; Stoddard, 2003).

The interpretive view of knowledge is that understanding social processes involves getting inside the world of those generating them (Orlikowski and Baroudi, 1991). It was therefore important to have an intimate understanding of the individuals and the context in which they work. The principal researcher already knew some of the participants for five years or more, and had interacted closely with some of them before the interviews took place. We adopted the perspective of Dent (1991), whereby we were primarily interested in establishing how the subjective interpretations of the respondents subsequently affected their actions in relation to professionalisation. This approach, combined with the role of the second researcher as an outsider in the data analysis phase, helped to address some of the potential bias issues in interpretive research related to there being close interaction between the principal researcher and the participants (Guba and Lincoln, 1994; Kakkuri-Knuuttila et al., 2008; Lee, 1991).

\section{Research setting}

The case organisation from which participants were drawn is an international medical humanitarian NGO with operations mostly in Africa, South America and Asia. The 
organisation has a long history of working in emergency/disaster settings and has therefore had prolonged exposure to, and interactions with, host governments. The organisation has Dunantist roots, i.e., it strongly believes in distancing itself from state interests. Dunantist organisations represent a specific subset of the broader humanitarian identity. This is relevant given that most of the operations in which they are involved are in settings where political crises or armed conflicts are present. The case organisation primarily deploys expatriate teams to places where they work. This is seen as ensuring proximity to the population being served while maintaining sufficient distance from the political situation to remain impartial and neutral. As a medical organisation, moral and ethical considerations with respect to drug quality assurance are of high importance. Logistics personnel are responsible for the sourcing and delivery of supplies, but not for the organisation's and the host governments' quality assurance policies and treatment protocols. As a consequence, they often have to comply with several standards, and these are not always aligned. This has a direct impact on logistics performance in terms of the timely delivery of the required supplies. An implication of this is that humanitarian logisticians experience the need to act to resolve such issues.

\section{Data collection}

Fifteen semi-structured interviews were conducted between December 2012 and March 2013. Most were conducted in March 2013 during a weeklong gathering of logistics personnel working either in the field or at headquarters (HQ). During this time, informal conversations and observations were also carried out.

\section{Respondents}

The unit of analysis is the individual, i.e. the humanitarian logisticians working for the IHO. The participants had work experience ranging from 6 to 25 years and therefore were knowledgeable about the complexities of the humanitarian context affecting their work. Of the fifteen respondents, five had a field posting and a Western background; five had an HQ posting and a Western background; and five had a field posting and a non-Western background. Most respondents had worked in several countries.

\section{Measurement}

The allocation of a dominant social identity typology to a respondent was based on two aspects: (a) the manner in which respondents described what they perceived as the nature of the problems they faced due to conflicting demands from the organisation and from host governments and (b) what they thought needed to change in order to improve the logistics function in the long term. In labelling the participants' identities, we made use of the social identities provided by Roccas and Brewer (2002) (Figure 1). For example, individuals were attributed with a 'humanitarian-dominance identity' if they fully accepted the humanitarian identity but only accepted those aspects of the professional identity that they considered compatible with the humanitarian identity. The converse balance would amount to a 'professional-dominance identity'. The logics for the remaining union and intersection identities are as described in Figure 1. 
Further, an emerging theme became evident from the data: boundary work. This was captured in the respondents' accounts of how they addressed and overcame logistical challenges faced as a result of the pressures from misaligned host government regulations, internal organisational policies and practices and/ or values and principles.

\section{Data analysis}

The first step in the analysis was to identify initial concepts in the data, which were then grouped into categories (open coding). First-order codes, i.e. language used by respondents (Van Maanen, 1979) or descriptive phrases, were used for the conceptual coding (Strauss and Corbin, 1990). The second step was to establish higher order themes, which was achieved through searching for relationships between and among the initial categories. The third and final step was to gather related themes into several overarching dimensions. The analysis was a "recursive, process-oriented, analytic procedure" as opposed to following a linear pattern (Locke, 1996: 240). This enabled a thorough understanding of the emerging theoretical relationships from the data. Appendix A provides a sample of representative quotes, the related themes, and interpretations where applicable. Given that certain quotes represent multiple codes, the first-order quotes have been colour-coded according to the themes they represent. The subsequent labels for the themes and interpretations are in the same colours as the quotes.

\section{Results and analysis}

\section{Adopted social identity profiles}

Individuals were found to adopt one of four social identity profiles (see Figure 2). The details for each individual are presented in Appendix B. In general, individuals appear, in practice, to face tensions over two main issues that need to be reconciled. First, although the moral intent of humanitarian organisations, to serve disaster victims, has historically given them autonomy in operational choices, the changing context now demands greater compliance with host government regulations. For example, governments increasingly forbid or make it difficult for IHOs to import supplies and insist on local purchase. Second, the case organisation's Dunantist notion of independence from host government influence has led to standoffs between the organisation and host governments in certain instances, which have had a negative impact on the effectiveness of operations. For example, access to affected populations has been hampered. How individuals make sense of these tensions has led to different social identities being adopted.

There are differences across these four identity profiles in terms of how they make sense of specific issues but, nevertheless, they still converge in terms of accepting or rejecting certain aspects of an identity. An example is how individuals with different social identity profiles made sense of governments' taxation of humanitarian supplies differently, but still drew the same conclusions about accepting it (see Box 1). 


\begin{tabular}{|c|c|c|c|}
\hline $\begin{array}{l}\text { PROFESSIONAL- } \\
\text { DOMINANCE }\end{array}$ & INTERSECTION & UNION & $\begin{array}{l}\text { HUMANITARIAN- } \\
\text { DOMINANCE }\end{array}$ \\
\hline $\begin{array}{l}\text { Four individuals have } \\
\text { this identity profile }\end{array}$ & $\begin{array}{l}\text { Three individuals } \\
\text { have this identity } \\
\text { profile }\end{array}$ & $\begin{array}{l}\text { Five individuals have } \\
\text { this identity profile }\end{array}$ & $\begin{array}{l}\text { Three individuals } \\
\text { have this identity } \\
\text { profile }\end{array}$ \\
\hline $\begin{array}{l}\text { Believe that, due to } \\
\text { sovereignty, host } \\
\text { government } \\
\text { regulations reign } \\
\text { supreme - even } \\
\text { when they do not } \\
\text { agree with those } \\
\text { regulations or the } \\
\text { basis of those } \\
\text { regulations. } \\
\text { Therefore, they tend } \\
\text { to embrace those } \\
\text { aspects of the } \\
\text { humanitarian } \\
\text { identity that do not } \\
\text { compromise this } \\
\text { affinity/ tolerance } \\
\text { for host government } \\
\text { regulations. }\end{array}$ & $\begin{array}{l}\text { Believe that the } \\
\text { humanitarian } \\
\text { identity and } \\
\text { regulations should } \\
\text { be intended to } \\
\text { uphold humanitarian } \\
\text { or human rights } \\
\text { issues (i) for an } \\
\text { entire population } \\
\text { (not just } \\
\text { beneficiaries), and } \\
\text { (ii) both in the short- } \\
\text { term and the long- } \\
\text { term. Therefore, } \\
\text { they reject aspects of } \\
\text { the humanitarian } \\
\text { identity, and have no } \\
\text { affinity/tolerance for } \\
\text { host government } \\
\text { regulations, that } \\
\text { they think stand in } \\
\text { the way of that. }\end{array}$ & $\begin{array}{l}\text { Believe that the } \\
\text { humanitarian } \\
\text { identity and host } \\
\text { government } \\
\text { regulations are, for } \\
\text { the most part, } \\
\text { unrelated issues that } \\
\text { each serve a specific } \\
\text { purpose, but accept } \\
\text { that these can } \\
\text { sometimes overlap } \\
\text { or be in conflict with } \\
\text { each other. } \\
\text { Therefore, they } \\
\text { embrace the } \\
\text { humanitarian } \\
\text { identity and have an } \\
\text { affinity/ tolerance } \\
\text { for host government } \\
\text { regulations. }\end{array}$ & $\begin{array}{l}\text { Believe that, due to } \\
\text { its intrinsically good } \\
\text { and well-intentioned } \\
\text { nature, the } \\
\text { humanitarian } \\
\text { identity reigns } \\
\text { supreme, even with } \\
\text { its limitations } \\
\text { regarding certain } \\
\text { issues (e.g. resolving } \\
\text { political issues and } \\
\text { providing long-term } \\
\text { solutions). } \\
\text { Therefore, they only } \\
\text { embrace those } \\
\text { aspects of host } \\
\text { government } \\
\text { regulations that they } \\
\text { do not perceive to } \\
\text { compromise the } \\
\text { humanitarian values } \\
\text { or principles. }\end{array}$ \\
\hline \multicolumn{2}{|c|}{ Most compliant with regulations } & \multicolumn{2}{|c|}{ Least compliant with regulations } \\
\hline
\end{tabular}

Figure 2: Social identities adopted 
Box 1: Differing perspectives on taxation, similar conclusions

IHOs have traditionally enjoyed exemption from taxes but they are increasingly required by host governments to pay them. There did not appear to be a strong opposition from the humanitarian logisticians regarding this. However, they rationalised this differently. For instance, a respondent with an intersection identity profile, and believing that humanitarian endeavours should not be outside the legal realm, reasoned that, when it comes to tax exemptions on the basis of an emergency, the state of emergency is defined by the host government. Thus, if the government does not declare a state of emergency, taxes should be paid. A respondent with a humanitariandominance identity profile also readily accepted taxation as normal and to be expected. He, however, accepted this only conditionally: the taxation process should be transparent enough to give assurance that genuine taxes are being paid, not bribes disguised as taxes. Thus, he was interested in the reasons behind the taxation. Another respondent, with a union identity, argued that paying taxes is a normal, regular part of conducting business, and accepted such regulations regardless of what a host government does with the tax collected. He argued that western governments purchase weapons with taxpayers' money and, even though he opposes this, he still pays his taxes in his home country.

\section{Boundary work}

An emerging finding in the research was that individuals employed various activities to resolve issues that affected logistics performance. We therefore went a step further in the research to establish how individuals use boundary work to resolve these issues with a focus on the implications this has for professionalisation. Participants discussed how they, on the one hand, would engage with their environment to gain support for their self-constructed identity and to protect their domain of expertise. This support was sought from both within and outside their own organisation. On the other hand, they discussed how they protect their humanitarian convictions against influence from the environment and, as a result, disengage with their environment. We labelled the former as 'engaging boundary work', i.e., gaining support and resources from the environment, which expresses a certain recognition and relevance. The latter was labelled as 'disengaging boundary work', and concerns activities that aim to express their own specific expertise, values and position. In addition to these enacted forms of boundary work, there was also often a desire among the individuals to engage in other boundary work activities, but none of them had yet acted on these desires. Such desires, related to various aspects, were expressed by 13 of the 15 participants, and so we incorporated this in the analysis and labelled it as 'desired boundary work'. Appendix C shows the boundary work of each individual in more detail.

\section{Engaging boundary work}

Engaging boundary work was enacted and/or desired by all respondents. Most of the enacted engaging boundary work involved having talks, meetings and negotiations with parties external to the organisation, and mainly host government officials. At the HOQ level, there were continuous efforts to, for instance, convince host governments that the organisation should be responsible for its own decisions and conduct, and could be trusted to bring in high 
quality drugs. At the field level, some logisticians within the IHO also engaged in reaching out to governmental institutions to find ways to get permission to import supplies into various countries in order to avoid the import problems the organisation would otherwise face.

Engaging with parties internal to the organisation involved trying to get other parties, for example, the IHO's medical staff, to alter their behaviour in ways that would facilitate improvements in logistics performance. In issues regarding medicines, the humanitarian logisticians were cautious in such approaches, often asking parties to investigate matters further rather than asking them to overturn their decisions. For example, logistics personnel spent years asking pharmacists to go to countries where they were having problems importing medicines to investigate what was going on and to come up with solutions in liaison with the relevant authorities.

Most respondents also showed desired engaging boundary work. Often, they felt the need to reach out more to host governments and to develop mechanisms to assist suppliers in guaranteeing supply in the face of tougher regulations.

\section{Disengaging boundary work}

All the instances uncovered of disengaging boundary work, be it enacted or desired, pertained to reinforcing issues specific to the humanitarian identity. An example of enacted disengaging boundary work is in responding to corruption. Most individuals refused to offer bribes under any circumstances, sometimes opting for delays and loss of supplies instead. Sometimes, disengaging boundary work is enacted to achieve positive outcomes. Holding firm to humanitarian principles was also sometimes perceived to pay off in terms of gaining access to a target population. Convincing host governments that its only interest was to offer direct assistance to civilians, and that the IHO was not politically influenced by any other actors, often led to the desired outcome of being granted access.

\section{Connecting social identity and boundary work}

Table 1 shows the social identity profiles, the boundary work by each individual, and the motivations for this. Even though individuals with different social identity types did boundary work for different purposes, there are overarching similarities across the profiles. In particular, aspects of professionalisation were generally reflected in responses to host government regulations, and enacting engaging boundary work was often expressed in contacts with government authorities. With the exception of the professional-dominance identity type, individuals with all the other social identity profiles used disengaging boundary work to reinforce their humanitarian identity. 


\begin{tabular}{|c|c|c|c|c|c|}
\hline \multirow[b]{2}{*}{ IDENTITY } & \multirow[b]{2}{*}{ R\# } & \multicolumn{2}{|c|}{ B/WORK } & \multicolumn{2}{|l|}{ PRIMARY MOTIVATIONS FOR BOUNDARY WORK (B/WORK) } \\
\hline & & En & Dis & ENGAGING (En) & DISENGAGING (Dis) \\
\hline \multirow{4}{*}{$\begin{array}{l}\text { Professional- } \\
\text { dominance }\end{array}$} & 3 & $\mathrm{x}$ & $\mathrm{x}$ & \multirow{4}{*}{$\begin{array}{l}\text { Host government authorities: understand what the regulations are in order } \\
\text { to comply. Involve or be involved with host government authorities to ensure } \\
\text { that rules are followed. } \\
\text { Very limited leeway for negotiation or requests for special 'favours' when } \\
\text { regulations are problematic. }\end{array}$} & \multirow{4}{*}{$\begin{array}{l}\text { Unconditionally relinquish } \\
\text { jurisdiction over matters } \\
\text { that are regulated by a host } \\
\text { government. }\end{array}$} \\
\hline & 21 & $x$ & $\mathrm{x}$ & & \\
\hline & 10 & $x, x$ & $\mathrm{x}$ & & \\
\hline & 14 & $x, x$ & $x, x$ & & \\
\hline \multirow[t]{6}{*}{ Intersection } & \multirow[t]{2}{*}{1} & $x$ & $x$ & \multirow{6}{*}{$\begin{array}{l}\text { Host government authorities: understand what host government regulations } \\
\text { are in place and why so as to evaluate whether compliance is acceptable. } \\
\text { Demonstrate goodwill with regard to complying with regulations. } \\
\text { Some provision for negotiation by 'asking for favours' from the host } \\
\text { government. } \\
\text { Other parties: to gain their support or convince them to take action that } \\
\text { facilitates understanding and/or compliance with host government } \\
\text { regulations. }\end{array}$} & \multirow{6}{*}{$\begin{array}{l}\text { Reinforce identity. } \\
\text { Relinquish jurisdiction over } \\
\text { matters that are regulated } \\
\text { by a host government on } \\
\text { condition that they are in } \\
\text { line with the aspects of the } \\
\text { humanitarian identity that } \\
\text { the individual embraces. }\end{array}$} \\
\hline & & $x$ & $\mathrm{x}$ & & \\
\hline & \multirow[t]{2}{*}{2} & $\mathrm{x}$ & $x$ & & \\
\hline & & $x$ & $x$ & & \\
\hline & \multirow[t]{2}{*}{4} & $\mathrm{x}$ & $\mathrm{x}$ & & \\
\hline & & $x$ & $x$ & & \\
\hline \multirow[t]{5}{*}{ Union } & 7 & $x, x$ & $x$ & \multirow{5}{*}{$\begin{array}{l}\text { Host government authorities: understand what the regulations are in order } \\
\text { to comply or negotiate new terms (this is sometimes done through other } \\
\text { parties as indicated by one respondent who had asked pharmacists to } \\
\text { conduct investigations in two countries. Also, when it is 'desired' } \\
\text { engagement, this seems to generally hold for instances when individuals are } \\
\text { of the opinion that other parties should be doing the boundary work). } \\
\text { There is considerable openness to negotiation on matters that are deemed } \\
\text { difficult to comply with or undesirable. }\end{array}$} & \multirow{5}{*}{$\begin{array}{l}\text { Reinforce identity. } \\
\text { Relinquish jurisdiction over } \\
\text { matters that are regulated } \\
\text { by a host government. It } \\
\text { was implied that this is } \\
\text { sometimes conditional (e.g. } \\
\text { when negotiation efforts } \\
\text { fail). }\end{array}$} \\
\hline & 22 & $x$ & $x$ & & \\
\hline & 17 & $x$ & $x$ & & \\
\hline & 9 & $x$ & $x, x$ & & \\
\hline & 13 & $x$ & $x$ & & \\
\hline \multirow{5}{*}{$\begin{array}{l}\text { Humanitarian- } \\
\text { dominance }\end{array}$} & \multirow[t]{2}{*}{5} & $x$ & $x$ & \multirow{5}{*}{$\begin{array}{l}\text { Host government authorities: understand what the regulations are and why } \\
\text { so as to able to negotiate and evaluate if compliance is acceptable. } \\
\text { Although respondents made it clear that engaging with the host government } \\
\text { is necessary, it is not immediately clear what they hoped to achieve from this. }\end{array}$} & \multirow{5}{*}{$\begin{array}{l}\text { Reinforce identity. } \\
\text { Relinquish jurisdiction over } \\
\text { regulations on the condition } \\
\text { that they are perceived to } \\
\text { be in line with their } \\
\text { humanitarian identity. }\end{array}$} \\
\hline & & $x$ & $x$ & & \\
\hline & 11 & $x$ & $x$ & & \\
\hline & \multirow[t]{2}{*}{19} & $x$ & $x$ & & \\
\hline & & X & & & \\
\hline
\end{tabular}

Table 1: The connection between social identity and boundary work 
The logisticians labelled with the intersection profile type were the most internally consistent with respect to the specific types of boundary work they. Not only were they found to enact/desire the same type of boundary work, they were also found to have the same motivations for it (Table 1).

Logisticians with a professional-dominance identity showed no evidence of disengaging boundary work, either enacted or desired. Perhaps this is not surprising given that this group sees compliance with host government regulations as critical. Given this viewpoint, such individuals are least likely to act to defend or reinforce the humanitarian identity when there is a perceived conflict between host government regulations and humanitarian endeavours. This, however, does not imply that they always support specific regulations.

The only consistency within the group of logisticians with a union identity was a shared desire to reject jurisdiction over certain aspects regulated by the host government. This group seemed to be the most relaxed in terms of reconciling the humanitarian and professional identities, being able to fully embrace both identities without subordinating one to the other. This group had more latitude for in choosing boundary work depending on the situation; i.e., they most readily used different approaches for different contexts in efforts to achieve the best possible outcomes.

No two individuals within the humanitarian-dominance identity group carried out the same form of boundary work (Table 1). This may reflect the different perceptions of the humanitarian identity within this group, with each individual's boundary work depending on how they embodied the humanitarian identity.

\section{Discussion and conclusions}

Since humanitarian logistics performance received much-needed attention in 2004, progress has been made with respect to understanding relevant factors for enabling performance improvement. Most of these efforts have undoubtedly been inclined towards professionalisation as they have, for example, focused on the application of skills from the commercial sector and identifying the necessary skills-set of humanitarian logisticians that are specific to their context of operation (Allen et al., 2013; Kovács et al., 2012; Moore and Taylor, 2011; Tatham and Pettit, 2010). Our research further demonstrates the crucial role of identity and its impact on convergence of norms, values, and practices in the quest for professionalisation. We identified four different social identity profiles based on how individuals reconcile the tensions between their humanitarian and professional identities: professional-dominance, intersection, union and humanitarian-dominance. It emerged that individuals also deployed boundary activities to gain support from within and from outside their organisation for their domain of expertise (engaging boundary work) and to close themselves off from other expertise domains (disengaging boundary work). This emerging finding is consistent with the findings of Tatham et al., (2017) who conclude that general management skills like relational and interpersonal capabilities are more important in complex environments than technical skills obtained through education and training. 


\section{Differences in acceptance of regulations across identities}

The affinity or tolerance for regulations differs across identity profile (Figure 2). For example, individuals with a professional-dominance identity believe it is the right of a host government to regulate humanitarian logistics activities and are highly inclined to be compliant sooner rather than later. On the contrary, individuals with a humanitariandominance identity generally believe that humanitarian values will sufficiently fit with any regulations that sincere host governments could possibly impose. They are likely to reject regulations that contradict their humanitarian beliefs.

These observed differences in accepting regulations across identities reflect the importance of understanding the influence of contextual aspects and the humanitarian identity in shaping the professional progression of the humanitarian logistics function (Heaslip et al., 2018). Resistance to professionalisation (which manifests as the rejection of certain host government regulations in this research), is a problem which is synonymous with developing professions that have origins in volunteerism (e.g., Nagel et al., 2015). Furthermore, the results of the research in this special issue also show that the adoption of new norms and practices in response to different contextual challenges can be hindered by conflicting belief systems among the individuals. In particular, Schneiker (2017) finds that these conflicts lead to resistance in adopting security risk management measures whereas Nelan et al., (2017) find that they can impede the adoption of standards aimed towards building agile supply chains in disaster relief. While this resistance can be misguided and undesirable, we caution that under certain circumstances, it is justified and should be given due consideration. Particularly in the humanitarian context, complexity and differences across settings warrant adapted responses that may not be served well by homogenisation of practices and policies (e.g., Donini, 1995, James, 2016, Slim, 2003). In addition, although certain host governments regulate humanitarian logistics for legitimate purposes, issues like corruption, politicisation and militarisation of aid remain concerns that humanitarian organisations continue to struggle with for valid reasons (e.g., Shannon, 2009).

\section{Boundary work and desired boundary work}

Individuals with different identity types can have similar or different goals when performing boundary work activities. For example, individuals with humanitarian-dominance, intersectional and union identity profiles were all found to conduct disengaging boundary work to reinforce their humanitarian identity. However, those with a professional-dominance identity use disengaging boundary work to relinquish their own jurisdiction on logistics aspects regulated by host governments. Further, it appeared that, at the current stage of the professionalisation of humanitarian logisticians, most aspects of boundary work are desired rather than actually enacted. Since boundary work has been defined as actions taken by individuals (Gieryn 1999, Faraj and Yan, 2009) we have coined the term "desired boundary work" to reflect this phase that potentially precedes enactment.

Despite differences in how logisticians seek to reconcile tensions between their humanitarian and professional identities, there appear to be general trends in individuals' motives for performing (or desiring) specific boundary work activities. Within their own organisation, 
humanitarian logisticians appear to be claiming jurisdiction and attempting to establish boundaries. They aim to establish a niche for themselves by advancing into a position of authority in terms of understanding host government regulations and going beyond the traditional logistics domain. They are becoming advisors to other professions about the best approaches for dealing with host government regulations and for raising the alarm when regulations start to become restrictive to the point of negatively affecting performance. Therefore, much of the logisticians' disengaging boundary work seems to take place within the organisational boundaries. Disengaging boundary work also tends to be used to protect the humanitarian identity. Given that the logistics function is only now emerging as a profession, the limited disengaging boundary work in relation to professional goals is perhaps unsurprising.

Externally, humanitarian logisticians are being pushed to relinquish jurisdiction over certain parts of the logistic function to host governments. As mentioned earlier, some logisticians see this as positive, because host government responsibilities to the public generally transcend the humanitarian scope of concern. For example, host governments can ensure the safety of the wider population through their protocols and standards, whereas humanitarian organisations' protocols and standards mostly benefit only that part of the population that is receiving humanitarian assistance. In such situations, our findings suggest that logisticians willingly cede jurisdiction to host governments. They also have a tendency, when matters fall outside of their own jurisdiction, to try to communicate to influential others why compliance is important. Therefore, much of their engaging boundary work goes beyond the organisational boundaries.

By becoming an authority on regulations outside their historical domain, and seeing the bigger picture with respect to the role of host government regulations, logisticians are making advances in terms of professionalisation. The more they succeed in these issues, the more this eases tensions for them, and the more they can achieve in terms of professionalisation and performance. However, since humanitarian logisticians currently adopt different social identity profiles, this could slow down the pace of professionalisation. Given the differences across operational settings, this may not necessarily be a negative outcome. As we show when we discuss implications for practice, each identity profile could be successful in certain settings.

The identified desired boundary work is insightful in two ways. First, it reveals the limitations of humanitarian logisticians in professionalising their function. These individuals are not the only ones making decisions on matters that directly impact on their ability to achieve good performance. They need to find ways to convince various other stakeholders to concede jurisdiction over certain matters. However, we found that, in many instances, they do not yet attempt this. Second, these desires suggest an evolving field where individuals are working towards a common understanding of the critical issues that affect their professionalisation and developing mechanisms to deal with the challenges they face in professionalising. Of interest is how they deal with this over time. 


\section{Implications for practice}

Social identity as a significant determinant of professionalisation should certainly be taken into account in training and education by bodies like the Humanitarian Logistics Association (HLA) and others. In addition to technical and managerial skills that a humanitarian logistician needs in dealing with context-related challenges (Heaslip et al., 2018), there is a clear need for the ability to deal with dilemmas that logisticians face in their daily work. For example, how they ought to deal with corruption and when they should compromise their beliefs for the greater good- if at all. We envision that taking such issues into account would imply a departure from the "attempt to put square pegs in round holes" through standardisation (James, 2016, p. 198).

The distinct social identity profiles identified in this research also imply differences in the level of pragmatism that individuals are likely to display in particular situations. Given that some host governments are stricter than others in regulating logistic activities, these differences can have consequences for the success of these individuals in different operational settings. For example, Dube et al. (2016) found that host governments adopt one of four stances in regulating humanitarian logistics activities. These include uncompromising host governments who tend to have strict regulations and be unwilling to adjust them regardless of their implications for performance and non-restrictive host governments who hardly regulate humanitarian logistics, thereby allowing logisticians considerable leeway in decision-making.

Comparing the host government typologies and the humanitarian logisticians' social identity profiles, the following can be deduced. Individuals with professional-dominance are most likely to thrive in environments where the host government is uncompromising as they are most inclined to accept host government regulations as a norm. This in turn enables them to quickly find ways to comply without compromising performance. Those with a humanitariandominance profile could do better when host governments are non-restrictive as their insistence of humanitarian values and principles would go unchallenged and would, therefore, carry no immediate performance implications. Therefore, at this stage, instead of pushing for standardised values, norms, and practices in relation to professionalisation of the humanitarian logistics function, it might be worthwhile to establish fit between the identity profiles and the varied operational environments that humanitarian organisations have to work in.

\section{Conclusions, limitations and future research}

In this paper, we set out to establish how humanitarian logisticians reconcile their wellestablished humanitarian identity with their developing professional identity in response to host government regulations. We found that individuals adopt one of four social identity profiles, namely professional-dominance, union, intersection or humanitarian-dominance. It emerged that individuals with a given social identity profile use (or desire) boundary work activities to achieve similar goals. This suggests that, during this phase of the professionalisation of humanitarian logistics, certain individuals are more suited to certain contexts than others, and we provided some illustrations. More research is needed to explore this issue in greater depth. 
There are three research limitations to be considered in future research. First, our research showed that, at least during the early stages of professional development, individuals can adopt different identity profiles and behaviours- which may be warranted in the humanitarian context. We think of the identity profiles we have identified as representing the collective conscience of the humanitarian logisticians and, given the diversity of contexts of operation, suppressing one over the other(s) in general could be ill-advised. It would be worthwhile to investigate if or how individuals eventually gravitate towards a single professional identity with universal norms, standards, practices and procedures without losing the individual differences that could potentially allow for innovation and adaptability. A second issue concerns what we labelled 'desired boundary work'. As this is an emergent aspect, its validity and potential value in understanding boundary work and professionalisation in general need further in-depth inquiry. Third, while we show significant behavioural differences in terms of boundary work among individuals based on their social identity profiles, we do not fully address the implications for performance in different contexts. Since behavioural operations research focuses on how individual and group behaviour can affect outcomes in performance and professionalisation (Galindo and Batta, 2013; Sankaranarayanan et al., 2018), it could be extended to capture, and better understand, identity issues and the dilemmas logisticians face in decision-making.

\section{References}

Abbey, E.M. (2008). "Constructive regulation of non-government organizations", The Quarterly Review of Economics and Finance, 48(2), 370-376.

Abbott, A. (1988). The System of Professions. An Essay on the Division of Labour. The University of Chicago Press, Chicago, IL.

Abbott, A. (1981). "Status and Status Strain in the Professions", American Journal of Sociology, 86(4), 819-835.

Allen, M.A., Kovács, G., Masini, A., Vaillancourt, A., Van Wassenhove, L.N. (2013) "Exploring the link between the humanitarian logistician and training needs", Journal of Humanitarian Logistics and Supply Chain Management, 3(2), 129-148.

Anagnostopoulos, D. (2006). “"Real Students' and 'True Demotes': Ending Social Promotion and the Moral Ordering of Urban High Schools." American Educational Research Journal, 43(1), 5-42.

Barker, T.J., Zabinsky, Z.B. (2010). "Designing for recovery”, Industrial Engineer, 42(4), $38-43$.

Barnett, M.N. (2013). "Humanitarian Governance", Annual Review of Political Science, 16, 379-398.

Barnett, M. (2005). "Humanitarianism transformed", Perspectives on politics, 3(4), 723-740. 
Barnett, M., Snyder, J. (2008). "The Grand Strategies of Humanitarianism", In Humanitarianism in Question: Politics, Power, Ethics, edited by Michael Barnett and Thomas G. Weiss, 143-71. Ithaca, NY: Cornell University Press.

Barnett, M., Weiss, T.G. (2008). "Humanitarianism: a brief history of the present", In Humanitarianism in Question: Politics, Power, Ethics, edited by Michael Barnett and Thomas G. Weiss, 143-71. Ithaca, NY: Cornell University Press.

Beijaard, D., Meijer, P.C., Verloop, N. (2004). "Reconsidering research on teachers' professional identity", In Teaching and Teacher Education, 20(2), 107-128.

Bratton, M., (1989). "The politics of government-NGO relations in Africa", World Development, 17(4), 569-587.

Brewer, M.B. (2001). "The social self: on being the same and different at the same time", in Hogg, M.A. and Abrams, D. (Eds), Intergroup Relations. Psychology Press, Hove, 245-253.

Cavana, R.Y., Delahaye, B.L., \& Sekaran, U. (2001). Applied business research: Qualitative and quantitative methods (Australian ed.). Milton, Queensland, Australia: J. Wiley.

Coburn, D. (2005). "Medical dominance then and now", Health Sociological Review, 15(5), 432-443.

Day, J.M., Melnyk, S.A., Larson, P.D., Davis, E.W., Whybark, D.C. (2012), "Humanitarian and disaster relief supply chains: a matter of life and death", Journal of Supply Chain Management, 48(2), 21-36.

De Leeuw, S. (2010), “Towards a reference mission map for performance measurement in humanitarian supply chains", IFIP International Federation for Information Processing, 181188.

Dent, J.F. (1991). "Accounting and organizational cultures: a field study of the emergence of a new organizational reality”, Accounting, organizations and society, 16(8), 705-732.

Dey, A., LaGuardia, P., Srinivasan, M. (2011) "Building sustainability in logistics operations: a research agenda", Management Research Review, 34(11), 1237-1259.

Donini, A. (1995). "Surfing on the crest of the wave until it crashes: intervention and the South." Journal of Humanitarian Assistance. https://sites.tufts.edu/jha/archives/67 Accessed on 10 November 2017.

Dube, N., Van der Vaart, T., Teunter, R.H., Van Wassenhove, L.N. (2016). "Host government impact on the logistics performance of international humanitarian organisations", Journal of Operations Management, 47, 44-57.

Duffield, M. (2007). Development, Security and Unending war: governing the world of peoples. Cambridge; Polity. 
Ergun, O., Karakus, G., Keskinocak, P., Swann, J., Villarreal, M. (2009). "Humanitarian Supply Chain Management-An Overview", In Models and Algorithms for Optimization in Logistics Dagstuhl Seminar Proceedings.

Faraj, S., Yan, A. (2009). "Boundary work in knowledge teams", Journal of Applied Psychology, 94(3), 604.

Fernandez, F.M., Green, M.D., Newton, P.N., (2008). "Prevalence and detection of counterfeit pharmaceuticals: a mini review”, Ind. Eng. Chem. Res., 47, 585-590.

Freidson, E., (1970). "Dominant Professions, Bureaucracy, and Client Services," in William R. Rosengren and Mark Lefton (eds.) Organizations and Clients: Essays in the Sociology of Service. Columbus, Ohio: Charles Merrill.

Galindo, G., Batta, R. (2013). "Review of recent developments in OR/MS research in disaster operations management”, European Journal of Operational Research, 230(2), 201-211.

Geertz, C. (1973). The Interpretation of Cultures. Basic Books, New York.

Gieryn, T.F. (1999). Cultural Boundaries of Science: Credibility on the Line. Chicago \& London: Univer

Grbic, N. (2010). ""Boundary work" as a concept for studying professionalization processes in the interpreting field", Translation and Interpreting Studies, 5(1), 109-123.

Guba, E.G., \& Lincoln, Y.S. (1994). Competing paradigms in qualitative research. In N.K. Denzin \& Y.S. Lincoln (Eds.), Handbook of qualitative research (pp. 105-117). Thousand Oaks, CA: Sage.

Heaslip, G., Tatham, P., Vaillancourt, A. (2018). "Developing Individual Competencies for Humanitarian Logistics", In: Kovács G., Spens K., Moshtari M. (eds) The Palgrave Handbook of Humanitarian Logistics and Supply Chain Management. Palgrave Macmillan, London.

Hilhorst, D. (2002). "Being good at doing good? Quality and accountability of humanitarian NGOs”, Disasters, 26(3), 193-212.

Holguín-Veras, J., Jaller, M., Van Wassenhove, L.N., Pérez, N., Wachtendorf, T. (2012). “On the unique features of post-disaster humanitarian logistics", Journal of Operations Management, 30(7-8), 494-506.

Hollweg, C., Wong, M-H. (2009). "Measuring regulatory restrictions in logistics services", ERIA Discussion Paper Series, no. 14.

Hotho, S. (2008). "Professional identity-product of structure, product of choice: linking changing professional identity and changing professions", Journal of Organizational Change Management, 21(6), 721-742. 
James, E. (2016), “The professional humanitarian and the downsides of professionalisation", Disasters, 40, 185-206.

Jussim, L., Ashmore, R.D., Wilder, D. (2001). "Introduction: social identity and intergroup conflict", in Ashmore, R.D., Jussim, L. and Wilder, D. (Eds), Social Identity, Intergroup Conflict and Conflict Reduction, Rutgers Series on Self and Social Identity, Vol. 3, Oxford University Press, Oxford, 3-16.

Kakkuri-Knuuttila, M. L., Lukka, K., Kuorikoski, J. (2008). "Straddling between paradigms: A naturalistic philosophical case study on interpretive research in management accounting", Accounting, Organizations and Society, 33(2), 267-291.

Kovács, G., Tatham, P., Larson, P. D. (2012). "What skills are needed to be a humanitarian logistician?", Journal of Business Logistics, 33(3), 245-258.

Kunz, N, Gold, S. (2017). "Sustainable humanitarian supply chain management - exploring new theory", International Journal of Logistics Research and Applications, 20(2), 85-104

Kunz, N., Reiner, G. (2012). “A meta-analysis of humanitarian logistics research", Journal of Humanitarian Logistics and Supply Chain Management, 2(2), 116-147.

Kunz, N., Reiner, G. (2016). "Drivers of government restrictions on humanitarian supply chains: An exploratory study", Journal of Humanitarian Logistics and Supply Chain Management, 6(3), 329-351.

Leader, N. (2000). The Politics of Principle: the Principles of Humanitarian Action in Practice. HPG Report 2, Overseas Development Institute, London.

Leininger, M.M. (1985). "Nature, rationale and importance of qualitative research methods in nursing”, In M.M. Leininger (Ed.), Qualitative research methods in nursing (pp. 1-28). New York: Grune \& Stratton.

Lee, A.S. (1991). "Integrating positivist and interpretive approaches to organizational research", Organization science, 2(4), 342-365.

Lin, C.Y., Ho, Y.H. (2011). "Determinants of green practice adoption for logistics companies in China", Journal of Business Ethics, 98(1), 67-83.

Locke, K. (1996). "Rewriting "The Discovery of Grounded Theory" after 25 years", Journal of Management Inquiry, 5, 239-245.

Moore, D.M., Taylor, D.H., (2011). "Humanitarian Logistics Professionalism", In (Christopher, M., \& Tatham, P., (Eds), Humanitarian Logistics, Kogan Page, 179-200.

Nagel, S., Schlesinger, T., Bayle, E., Giauque, D. (2015). "Professionalisation of sport federations - a multi-level framework for analysing forms, causes and consequences", European Sport Management Quarterly, 15(4), 407-433. 
Nancarrow, S.A., Borthwick, A.M. (2005). "Dynamic professional boundaries in the healthcare workforce", Sociology of Health and Illness, 27(7), 897-919.

Nelan, M., Wachtendorf, T., Penta, S. (2018). "Agility in Disaster Relief: A Social Construction Approach", Risk Hazards \& Crisis in Public Policy, 9(2), [online early view]

Operariro, D., Fiske, S.T. (1999). "Integrating social identity and social cognition: a framework for bridging diverse perspectives", in Abrams, D. and Hogg, M.A. (Eds), Social Identity and Social Cognition, Blackwell, Oxford, 26-54.

Orlikowski, W. J., Baroudi, J. J. (1991). "Studying information technology in organizations: Research approaches and assumptions", Information systems research, 2(1), 1-28.

Pache, A.C., Santos, F. (2010). "When worlds collide: The internal dynamics of organizational responses to conflicting institutional demands", Academy of management review, 35(3), 455-476.

Pohlen, T. (2011). "Meeting the Challenge of Educating the Transportation and Logistics Professional: The American Society of Transportation and Logistics on the 50th Anniversary of Transportation Journal", Transportation Journal, 50(1), 84-90.

Rahman, S., Wu, Y-C. J. (2011). "Logistics outsourcing in China: the manufacturer-cumsupplier perspective", Supply Chain Management: An International Journal, 16(6), 462-473.

Roccas, S., Brewer, M.B. (2002). "Social identity complexity", Personality and Social Psychology Review, 6(2), 88-106.

Sankaranarayanan, K., Castañeda, J.A., Villa S. (2018). "Future Research in Humanitarian Operations: A Behavioral Operations Perspective”, In: Kovács G., Spens K., Moshtari M. (eds) The Palgrave Handbook of Humanitarian Logistics and Supply Chain Management. Palgrave Macmillan, London

Schwandt, T.A. (1994). "Constructivist, interpretivist approaches to human inquiry", In N. K. Denzin \& Y. S. Lincoln (Eds.), Handbook of qualitative research (pp. 118-137). Thousand Oaks, CA: Sage.

Schneiker, A. (2018). "Risk-Aware or Risk-Averse? Challenges in Implementing Security Risk Management within Humanitarian NGOs", Risk Hazards \& Crisis in Public Policy, 9(2), [online early view]

Seekins, D.M. (2009). "State, Society and Natural Disaster: Cyclone Nargis in Myanmar (Burma).” Asian Journal of Social Science, 37(5), 717-737.

Shannon, M. (2009). "Playing with principles in an era of securitized aid: negotiating humanitarian space in post-9/11 Afghanistan”, Progress in Development Studies, 9(1), 15-36.

Silve, B., Ouedraogo, A. (2013). "Professionalizing Health Logistics in Burkina Faso: Challenges, Implementation and Sustainability", Public Health Research, 3(6),157-161. 
Slim, H. (2003). "Humanitarianism with borders? NGOs, belligerent military forces and humanitarian action", Presented at the International Council of Voluntary Agencies (ICVA) Conference on 'NGOs in a changing world order: dilemmas and challenges', Geneva, Switzerland,

February. http://repository.forcedmigration.org/show_metadata.jsp?pid=fmo:2718 Accessed on 1 November 2017.

Smith, S.L. (2011). "An Analysis of Authority Issues within National Response Framework ESF\# 6-Mass Care, Housing and Human Services Policy", Risk, Hazards \& Crisis in Public Policy, 2(3), 1-14.

Stoddard, A. (2003). Humanitarian NGOs: Challenges and Trends. London: Overseas Development Institute.

Strauss, A., Corbin, J. (1990). Basics of Qualitative Research. (Vol. 15) Newbury Park, CA: Sage publications

Stuart, I., McCutcheon, D., Handfield, R., McLachlin, E., Samson, D. (2002). "Effective research in operations management: a process perspective", Journal of Operations Management, 20(5), 419-433.

Tajfel, H. (1982). Social Identity and Intergroup Relations. Cambridge University Press, London.

Tatham, P. H., Pettit, S.J. (2010). "Transforming humanitarian logistics: the journey to supply network management", International Journal of Physical Distribution \& Logistics Management, 40(8/9), 609-622.

Tatham, P., Wu, Y., Kovács, G., Butcher, T. (2017). "Supply chain management skills to sense and seize opportunities", The International Journal of Logistics Management, 28(2), 266-289.

Thomas, A., Kopczak, L. (2005). From logistics to supply chain management. The path forward in the humanitarian sector. USA: The Fritz Institute.

Tyler, T.R., Dienhart, J., Thomas, T. (2008). "The ethical commitment to compliance: building value-based cultures", California Management Review, 50(2), 31-51.

Van Maanen, J. (1979). "The fact of fiction in organi-zational ethnography", Administrative Science Quarterly, 24, 539-550.

Walker, P. (2004). "What does it mean to be a professional humanitarian", The Journal of Humanitarian Assistance, 14.

Walker, P., Russ, C. (2011). "Fit for purpose: the role of modern professionalism in evolving the humanitarian endeavour," International Review of the Red Cross, 93(884), 1193-1210. 
Walker, P., Russ, C. (2010). Professionalising the humanitarian sector: A scoping study. Enhancing Learning and Research for Humanitarian Assistance. Cardiff, United Kingdom: Enhanced Learning and Research for Humanitarian Assistance.

Walker, P., Hein, H.K, Russ, C., Bertleff, G., Caspersz, D. (2010). "A Blueprint for Professionalizing Humanitarian Assistance: Good Intentions Are Not Enough", Health Affairs, 29(12), 2223-2230.

Weiss, T.G., (1999). "Principles, Politics, and Humanitarian Action.” Ethics \& International Affairs, 13(1), 1-22.

Welling, D. R., Ryan, J. M., Burris, D. G., Rich, N. M. (2010). "Seven sins of humanitarian medicine", World journal of surgery, 34(3), 466-470.

Zotova, N. K., Ganaeva, E. A., Maslovskaya, S. V. (2014). "Humanitarian expertise of the personalized model of supplementary professional education of the educational establishment principals", Life Science Journal, 11(12-C), 386-389. 
Appendix A: Sample representative quotes and interpretations 


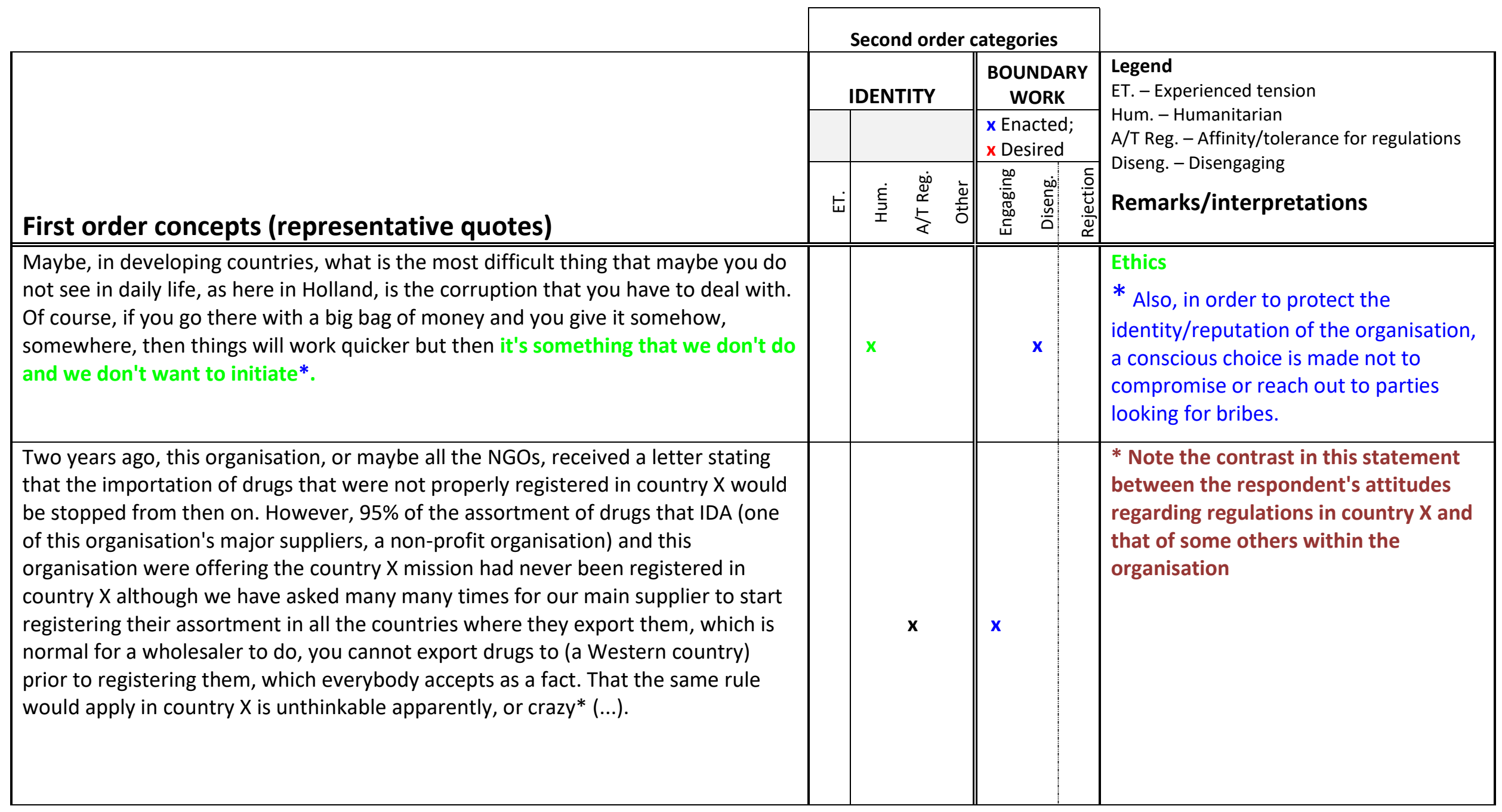




\begin{tabular}{|c|c|c|c|c|c|}
\hline $\begin{array}{l}\text { But it seems a bit old fashioned to me that it (quality control/assurance) applies to } \\
\text { our own operations*. So, provided people are being treated in our facility, they } \\
\text { should have the best drugs in the world, but as soon as they are discharged or } \\
\text { released, they have to buy their drugs in the drug store, at the market, in the } \\
\text { street and anything goes there. So what is the purpose we are maintaining?** } \\
\text { I do think we do have the obligation to ensure quality but we are not an island, } \\
\text { you are operating in a whole society, economy, country*... (laughs). }\end{array}$ & $x$ & $\mathbf{x}$ & & $x$ & $\begin{array}{l}\text { Ethics } \\
\text { ** Observed tension with quality } \\
\text { assurance/control as it applies only to } \\
\text { the organisation. Respondent also uses } \\
\text { this ethical argument to justify } \\
\text { engaging with host governments for } \\
\text { overall quality control/assurance } \\
\text { * Implies that jurisdiction over actual } \\
\text { quality control should be the } \\
\text { responsibility of the host government. }\end{array}$ \\
\hline $\begin{array}{l}\text { We believe that we are there as gap fillers. We are not going to change the } \\
\text { situation but we will resolve some of the suffering, you know, alleviate some of the } \\
\text { suffering on a temporary basis. But, that temporary basis usually lasts only months, } \\
\text { but it can also last years and sometimes decades, because you can't actually tell } \\
\text { when changes will come. }\end{array}$ & & $x$ & $\mathbf{x}$ & & $\begin{array}{l}\text { Temporary, apolitical } \\
\text { This is actually in line with the apolitical } \\
\text { nature of humanitarian organisations. }\end{array}$ \\
\hline $\begin{array}{l}\text { If you really think about it, I would say, when you jump in at the moment the } \\
\text { emergency happens (without an invitation from the host government) to try to } \\
\text { save as many lives as possible you do it from a moral point of view, you actually } \\
\text { feel that you are doing the right thing that way. I am happy that we are in the } \\
\text { mode to do it that way. But, on the other hand, I don't completely blame the side } \\
\text { of the host governments either, because it is in power in a way, no matter how, } \\
\text { whether their power is legitimate or not, it's not up to us to judge. It's up to the } \\
\text { people and the community. And sometimes okay, yes, people don't have the } \\
\text { power and they can't (change the situation), but we don't (have the power) } \\
\text { either (...). }\end{array}$ & $x$ & $x$ & $\mathbf{x}$ & & $\begin{array}{l}\text { In line with Dunantist thinking, } \\
\text { alleviating suffering is the main } \\
\text { concern, government consent is a } \\
\text { secondary issue. } \\
\text { view of not having the power to change } \\
\text { the situation, and thus not trying to } \\
\text { change the (political) situation, } \\
\text { reinforces the humanitarian identity of } \\
\text { being apolitical. }\end{array}$ \\
\hline $\begin{array}{l}\text { What I never understand is that this whole bureaucratic process does not seem } \\
\text { to have a really very good reason for why it takes so long. Because they don't } \\
\text { check quality, they don't ask you for any quality documentation, they don't ask } \\
\text { you the exact origin of each product (...) If I would be like a crooked business } \\
\text { man, I could import } 10,20 \text { containers full of fake drugs and nobody would be able } \\
\text { to stop it because there is no quality check mechanism. }\end{array}$ & & $\mathbf{x}$ & & & $\begin{array}{l}\text { Respondent points out that certain } \\
\text { regulations are not effective enough to } \\
\text { add value for the population, implying } \\
\text { conditional acceptance of regulations. }\end{array}$ \\
\hline
\end{tabular}




\begin{tabular}{|c|c|c|c|c|}
\hline $\begin{array}{l}\text { It's an emphasis on independence, specifically with this organisation I think. I } \\
\text { mean we pride ourselves on it and we pride ourselves rightly for it because it has } \\
\text { a lot of benefits for us and a lot of benefit for the target populations that we } \\
\text { choose. But I think we have to (...) be a little bit modest, or moderate at least, } \\
\text { and sometimes that will get us further* than to repeatedly run headlong into a } \\
\text { brick wall in the hope that eventually, although it hurts, the bloody wall will break. } \\
\text { Sometimes it's good to do it, but sometimes it also makes no sense*. }\end{array}$ & $\mathbf{x}$ & $x$ & $\mathbf{x}$ & $\begin{array}{l}\text { Independence, how this principle is } \\
\text { interpreted is sometimes problematic. } \\
\text { Generally, takes pride in this aspect of } \\
\text { the organisation's identity despite } \\
\text { shortcomings. } \\
\text { Observed tension, also suggests that } \\
\text { there is a need to sometimes yield to } \\
\text { host government } \\
\text { demands/preferences. } \\
{ }^{*} \text { Respondent notes that sometimes } \\
\text { reaching out is more important than } \\
\text { preserving the principle of } \\
\text { independence in order to get required } \\
\text { results. }\end{array}$ \\
\hline $\begin{array}{l}\text { At the moment, for me, the government has become a stronger state and they } \\
\text { have set different rules and regulations. At the same time, they are working to } \\
\text { improve the life of the population. So that now, when you see most of the NGOs, } \\
\text { many are not happy with the government regulations. To me, it is a matter of, you } \\
\text { know, understanding or complying with the government* who is handling the } \\
\text { lives of millions of people for a longer period. } \\
\text { It is a matter of complying with a short-term strategy or incorporating a short-term } \\
\text { strategy in the long-term strategy of the government. As I said, because of this } \\
\text { standoff sometimes the beneficiaries are not addressed because NGOs want to } \\
\text { impose their own strategy and the government says no. At the same time, the } \\
\text { government does not have the capacity to address all the population. }\end{array}$ & & $x$ & $\mathbf{x}$ & $\begin{array}{l}\text { Here, humanitarian values are used as } \\
\text { an argument for } \\
\text { acceptance/correspondence of } \\
\text { regulations. } \\
\text { * Desire to relinquish jurisdiction over } \\
\text { certain issues also implied. } \\
\text { Respondent notes how non- } \\
\text { compliance with regulations implies } \\
\text { that the needs of populations in } \\
\text { distress are not met and that this } \\
\text { contradicts humanitarian 'core } \\
\text { business'. }\end{array}$ \\
\hline
\end{tabular}




\begin{tabular}{|c|c|c|c|c|}
\hline $\begin{array}{l}\text { For NGOs (...) if the main objective is beneficiaries, they need to at least review } \\
\text { their strategy, review their focus, and address first the patients or beneficiaries and } \\
\text { start to negotiate with the government(1)*. All of us (NGOs and host } \\
\text { governments) are working to avoid such disasters.(...) I am sure the NGOs are } \\
\text { happy if there is a way to avoid or eliminate such disasters happening again. I think } \\
\text { the government has this strategy, I don't think the NGOs have this one }(2)^{* *} \text {. That } \\
\text { is why there is a need to work together*. }\end{array}$ & $x$ & $\begin{array}{ll}\mathbf{X}( & \mathbf{X}( \\
1) & 2)\end{array}$ & & $\begin{array}{l}\text { Helping victims of man-made or natural } \\
\text { disasters } \\
\text { Desired engagement with the host } \\
\text { government through negotiation, } \\
* * \text { Reinforces the idea that long-term } \\
\text { considerations are the responsibility of } \\
\text { the host government, which gives them } \\
\text { the right to regulate matters of long- } \\
\text { term relevance } \\
* \text { also reveals rejection of the } \\
\text { organisation's modus operandi of } \\
\text { tending to work independently of host } \\
\text { governments. }\end{array}$ \\
\hline $\begin{array}{l}\text { Regulations around the need to buy drugs locally - in some countries, like country } \\
\text { X, they don't allow that you just import drugs into their country. I think that's their } \\
\text { right, for a country to say okay we have our own quality system, and it's our right } \\
\text { to have it. We allow just these drugs, so you have to take these drugs. I think that's } \\
\text { perfectly alright. Maybe for some very specific reasons or protocols you can discuss } \\
\text { that, but then discuss it with the authorities(1) rather than engage in very high- } \\
\text { level advocacy }(2)^{*} \text {. }\end{array}$ & $\mathbf{x}$ & $\begin{array}{l}\mathbf{X}( \\
1)\end{array}$ & $\begin{array}{l}\mathbf{x}( \\
2)\end{array}$ & $\begin{array}{l}\text { Respondent believes that problems } \\
\text { with conflicting protocols between } \\
\text { host government and this organisation } \\
\text { should be resolved by engaging in } \\
\text { dialogue with the host government. } \\
\text { * Also, rejection of one aspect of } \\
\text { identity and the action it leads to: } \\
\text { advocacy. }\end{array}$ \\
\hline
\end{tabular}




\begin{tabular}{|c|c|c|c|c|c|}
\hline $\begin{array}{l}\text { As long as they don't care [host governments], we can do what we want to do. } \\
\text { And you can see it as positive, like oh they're supportive (pause) no they're not } \\
\text { supporting at all! They just don't care! They don't care about the people, they } \\
\text { don't care about quality, they don't care who we are. Maybe they will try to get } \\
\text { some bribes, but maybe they will also understand that we [don't offer bribes] so } \\
\text { they will try to get bribes from somebody else. So they don't care. And we are used } \\
\text { to working in countries where governments are non-existent, or they don't care, } \\
\text { authorities are corrupt (...). }\end{array}$ & & $x \quad x$ & $x$ & & $\begin{array}{l}\text { Respondent argues for upholding } \\
\text { regulations as a means of ensuring that } \\
\text { populations get access to quality } \\
\text { healthcare/medicines. } \\
\text { In line with the humanitarian impulse } \\
\text { of concern for others: for victims of } \\
\text { disaster } \\
\text { Reinforcement of humanitarian identity } \\
\text { with respect to ethics. }\end{array}$ \\
\hline $\begin{array}{l}\text { Of course, this organisation started as an organisation that (...) crossed lines that } \\
\text { were set up by bad people, let's put it like that. And we should still keep on doing } \\
\text { that. But let's distinguish between obstruction because they don't want } \\
\text { humanitarian help or obstruction because they have their own rules and we need } \\
\text { to learn that ... And mind you, I am talking about country X. If you would ask me } \\
\text { the same thing about country T then it's a complete different story, because there } \\
\text { everything is done to make our life difficult. }\end{array}$ & $x$ & $x$ & $\mathbf{x}$ & & $\begin{array}{l}\text { Dunantist approach to humanitarian } \\
\text { work. } \\
\text { Respondent observes that issues } \\
\text { related to identity and } \\
\text { policy/regulations tend to be mixed } \\
\text { up. }\end{array}$ \\
\hline $\begin{array}{l}\text { (On resistance to paying taxes) Why would we not want to pay taxes? I pay taxes } \\
\text { here as well. It's so normal that you pay taxes... [If the government abuses it] } \\
\text { that's not our concern (1). I also don't like it when they buy strike fighters (with } \\
\text { my tax money here in Holland) but that's the government, I pay my taxes, it's } \\
\text { normal. (...) But if we, for whatever reason, think that we should not pay taxes, } \\
\text { yeh, fine but let's negotiate (2). }\end{array}$ & & & $\begin{array}{l}\mathbf{X}( \\
2)\end{array}$ & $\begin{array}{l}\mathbf{X}( \\
1)\end{array}$ & $\begin{array}{l}\text { (1) Respondent is of the opinion that, if } \\
\text { a government demands taxes, these } \\
\text { should be paid even when the } \\
\text { organisation does not agree with how } \\
\text { the tax revenue is used. } \\
\text { (2) Since he believes it is a } \\
\text { government's right to charge taxes, he } \\
\text { feels that if the organisation does not } \\
\text { agree with this then they should seek } \\
\text { to negotiate other terms rather than } \\
\text { dismiss the regulation. }\end{array}$ \\
\hline
\end{tabular}




\begin{tabular}{|c|c|c|c|c|c|}
\hline $\begin{array}{l}\text { We, in the end, are also what we are (...) Our notion is not like let's get operational, } \\
\text { let's do an emergency in Eastern country X, let's start by buying a suit and a tie, } \\
\text { polish our shoes and have a round of serious talks with country X's government. It } \\
\text { should be. You wish we could. You wish we could find people who are capable of } \\
\text { doing it. But our notion is LET'S GET IN THERE!! And the thing is you need that } \\
\text { notion (of let's get in there) because the job is hard enough, there's enough } \\
\text { obstacles whether intentional or circumstantial that block your progress. You need } \\
\text { a lot of drive, you need a lot of balls, you need a lot of arrogance to get going. } \\
\text { Unfortunately, that attitude that you need for one thing, doesn't necessarily } \\
\text { facilitate the other. Of course, in an ideal world you would have all the attitudes in } \\
\text { your team composition. }\end{array}$ & $\mathbf{x}$ & $x$ & $\mathbf{x}$ & & $\begin{array}{l}\text { This is also a reference to the } \\
\text { Dunantist approach, getting aid where } \\
\text { it is needed without the burden of } \\
\text { dealing with governments. } \\
\text { Observed tension between what can } \\
\text { be achieved by being daring and } \\
\text { arrogant and what can be lost through } \\
\text { the same approach. }\end{array}$ \\
\hline $\begin{array}{l}\text { Indeed I think what you have to negotiate and talk about when presenting } \\
\text { yourself should be principles and not policies. And why do we confuse them? } \\
\text { Because we're human, and indeed because we're also inclined to somehow see } \\
\text { ourselves as... (pause) everybody wants to see the world through their own pair of } \\
\text { glasses. So, of course, our principles are universal but, having said that, then we } \\
\text { can immediately discuss my practical policies coming out of this. But it takes quite } \\
\text { an effort to see that your principles are probably to a large extent only your } \\
\text { principles, and not necessarily shared by the other person. }\end{array}$ & & & & $\mathbf{x}$ & $\begin{array}{l}\text { Respondent questions whether } \\
\text { humanitarian principles are indeed } \\
\text { universal. }\end{array}$ \\
\hline
\end{tabular}


Appendix B: Identity profiling per individual 


\begin{tabular}{|c|c|}
\hline $\begin{array}{l}\text { Respondent } \\
\text { number } \\
\text { (R\#) }\end{array}$ & Justification \\
\hline 1 & $\begin{array}{l}\text { Respondent appears comfortable with the organisation's stance of 'not there to make } \\
\text { everybody happy', explicitly mentions uncompromising nature of the organisation } \\
\text { when it comes to bribery but criticises the organisation for not being swift to respond } \\
\text { to changing/new regulations. While he strongly feels that it is necessary to follow } \\
\text { host government regulations, he states that it matters why those regulations are in } \\
\text { place by suggesting that the organisation should try to know the reasons for specific } \\
\text { regulations. He gives a specific example about local purchasing in Ethiopia where he } \\
\text { believes the quality of the drugs is unacceptable, implying that, in such situations, } \\
\text { compliance would not be desirable because it could do more harm than good. }\end{array}$ \\
\hline 2 & $\begin{array}{l}\text { Respondent feels that certain aspects of the humanitarian identity (e.g. being rule } \\
\text { averse as shown by the use of the term 'cowboy-like organisation') are no longer } \\
\text { relevant for the challenges now faced in humanitarian work. However, he also } \\
\text { appears to appreciate regulations that are in place for the advancement of a country, } \\
\text { as in the case of Ethiopia where these were to do with controlling counterfeit } \\
\text { medicines. }\end{array}$ \\
\hline & $\begin{array}{l}\text { For this respondent, the importance of regulations and following them dominate. He } \\
\text { notes that, even if rules are sometimes 'irrational', the only way to deal with the } \\
\text { situation is to comply. }\end{array}$ \\
\hline 4 & $\begin{array}{l}\text { Respondent states explicitly that he does not 'advocate' the Dunantist identity aspect } \\
\text { of dissociation from the government. In addition, while he recognises rules as } \\
\text { important, he only argues in support of upholding those that are in line with } \\
\text { humanitarian thinking. For example, he argues that quality assurance should apply to } \\
\text { the wider population of a country and not just to those being served by the } \\
\text { organisation. On that basis, it makes sense to him that the host government should } \\
\text { be the main authority in terms of quality control, and that the organisation's policies } \\
\text { should be subordinate to those of the host. }\end{array}$ \\
\hline & $\begin{array}{l}\text { Respondent believes in the causes of humanitarian organisations and thinks that the } \\
\text { humanitarian identity should be preserved for the general good. In addition, he } \\
\text { believes that regulations should have a meaningful purpose as revealed by his } \\
\text { questioning of regulations that do not ensure quality control of drugs where the aim } \\
\text { should be to ensure the safety of the population. }\end{array}$ \\
\hline & $\begin{array}{l}\text { Respondent does not voice any opposition to the humanitarian identity, but neither } \\
\text { does he oppose certain host government regulations that can limit humanitarian } \\
\text { organisations' freedom to operate. In particular, he considers the government control } \\
\text { of movements in insurgency areas as normal military operations and accepts that } \\
\text { challenges will be faced when a government is disinterested in allowing humanitarian } \\
\text { access to certain areas. }\end{array}$ \\
\hline & $\begin{array}{l}\text { Respondent generally appears to take pride in the humanitarian identity but, at the } \\
\text { same time, accepts that host governments have a right to regulate the environment } \\
\text { in which humanitarian organisations work. Although he does not believe that the } \\
\text { humanitarian identity and host government requirements are always reconcilable, he } \\
\text { thinks that they are both to an extent justified. }\end{array}$ \\
\hline & $\begin{array}{l}\text { Respondent holds host government regulations in high regard and believes that they } \\
\text { are for the long-term benefit of the entire population. Even though he also holds the } \\
\text { humanitarian identity in high regard, he explicitly mentions that he believes certain } \\
\text { aspects of the humanitarian identity should be compromised in order to make space } \\
\text { for longer term development and so that the humanitarian organisation can access } \\
\text { affected populations. }\end{array}$ \\
\hline & $\begin{array}{l}\text { Respondent holds the humanitarian identity in high regard and, while he values a } \\
\text { good regulatory environment, he also believes that it matters why regulations are put } \\
\text { in place. If rules/regulations are not in line with the humanitarian identity, then he } \\
\text { does not value them. He gives an example of the difference between regulations that } \\
\text { are meant to protect the population through better quality assurance and rules that }\end{array}$ \\
\hline
\end{tabular}




\begin{tabular}{|c|c|}
\hline & $\begin{array}{l}\text { are in place to protect local business people. The latter he sees as more in line with } \\
\text { development goals. }\end{array}$ \\
\hline & $\begin{array}{l}\text { Respondent appears to take a more liberal view of identity. He accepts the } \\
\text { humanitarian identity and its flaws, but is of the opinion that it is important to 'deal } \\
\text { with' the host government and have 'enough consideration for what is involved for } \\
\text { you to get yourself in place'. }\end{array}$ \\
\hline & $\begin{array}{l}\text { Respondent holds host government regulations in high regard and thinks that it is a } \\
\text { host government's 'right' to develop their own quality system. He recognises that } \\
\text { regulations are sometimes incompatible with the humanitarian identity but does not } \\
\text { seem to see this as a basis for non-compliance. Rather, he seems to suggest that, in } \\
\text { such instances when regulations are considered problematic for the organisation, } \\
\text { there should be discussion with the host government. }\end{array}$ \\
\hline & $\begin{array}{l}\text { Respondent takes the view that humanitarian identity and regulations are two } \\
\text { separate issues that need not be at odds with one another. For instance, he notes } \\
\text { that the roots of the organisation are in 'crossing lines that were set up by bad } \\
\text { people' and that this should continue, but also points out that when governments } \\
\text { choose to have their own rules this does not make them bad people. There is a } \\
\text { perceived degree of overlap that derives from his argument that governments that do } \\
\text { not put regulations in place do not actually care about the population. }\end{array}$ \\
\hline & $\begin{array}{l}\text { Respondent recognises both merits and negative aspects in the humanitarian identity } \\
\text { but appears to fully embrace it nonetheless. He also thinks host government } \\
\text { regulations are acceptable as long as they do not stand in the way of humanitarian } \\
\text { goals and advance the broader cause of ensuring safety for all in terms of drugs. }\end{array}$ \\
\hline & $\begin{array}{l}\text { Respondent fully believes that regulations are meant to assure good practices and } \\
\text { sustainability. Perhaps because of this, the respondent believes that the humanitarian } \\
\text { identity should be adapted to the regulations. This was revealed by her statement } \\
\text { that 'you now want those rules to fit with what you want to do to the patient' } \\
\text { (meaning that rules should be followed while the organisation offers treatment to } \\
\text { patients). }\end{array}$ \\
\hline & $\begin{array}{l}\text { Respondent holds the humanitarian identity in high regard. Although she recognises } \\
\text { that this is not always compatible with the regulations in place, such regulations are } \\
\text { not dismissed as unacceptable. Rather, the respondent thinks it is important to } \\
\text { demonstrate that the organisation has respect for the regulations when she talks } \\
\text { about truly convincing host government authorities 'that we are not there to } \\
\text { undermine, but to help'. }\end{array}$ \\
\hline
\end{tabular}




\title{
Appendix C: Boundary work per individual
}

\author{
$\underline{\text { Key }}$ \\ Posting \\ $\mathrm{F} \quad$ Field posting \\ $\mathrm{HQ} \quad$ Headquarters posting \\ Background \\ W Western background \\ $\mathrm{N}-\mathrm{W} \quad$ Non-western background \\ Boundary work \\ $X \quad$ Actual (enacted) boundary work \\ $X \quad$ Desired boundary work
}




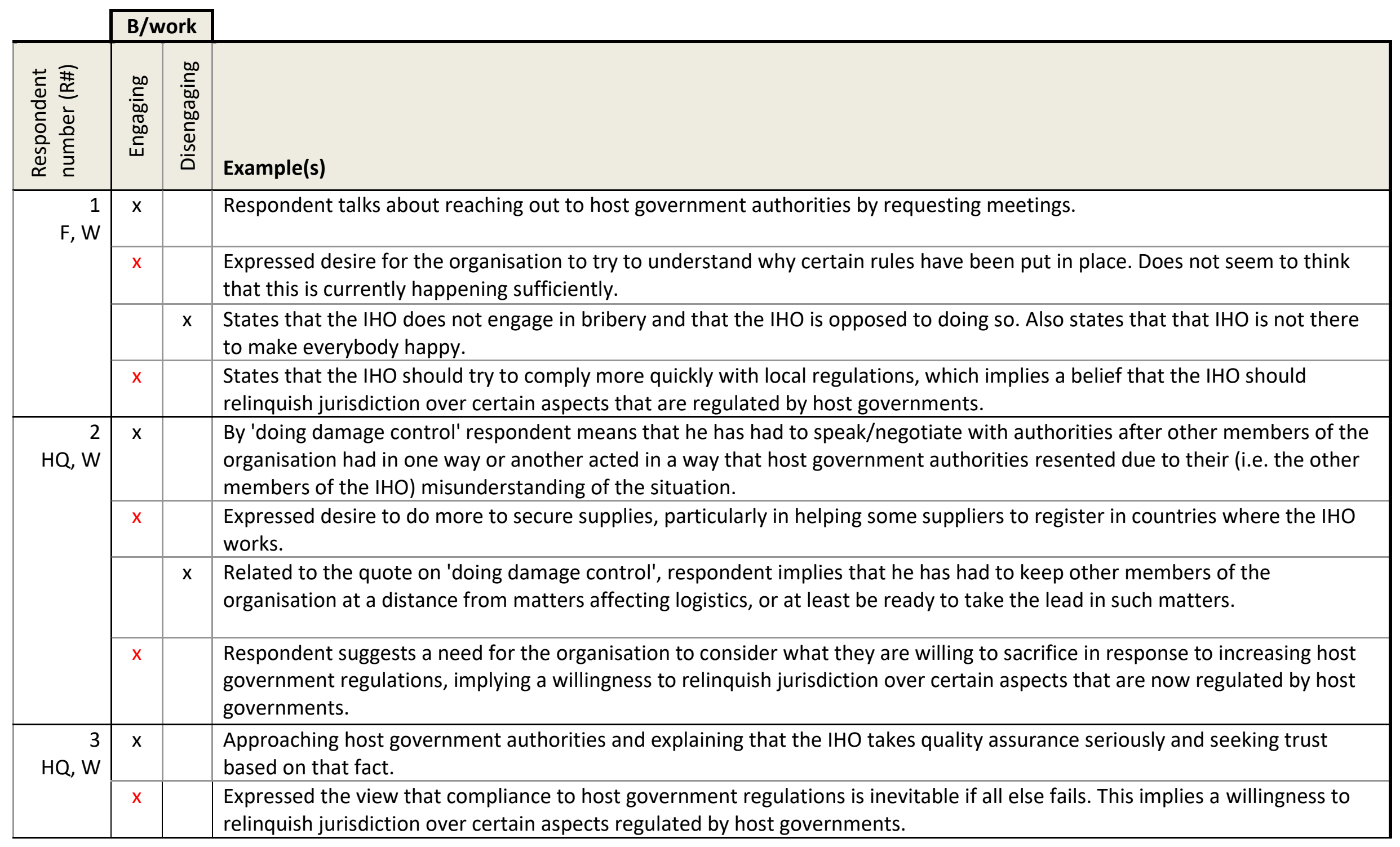




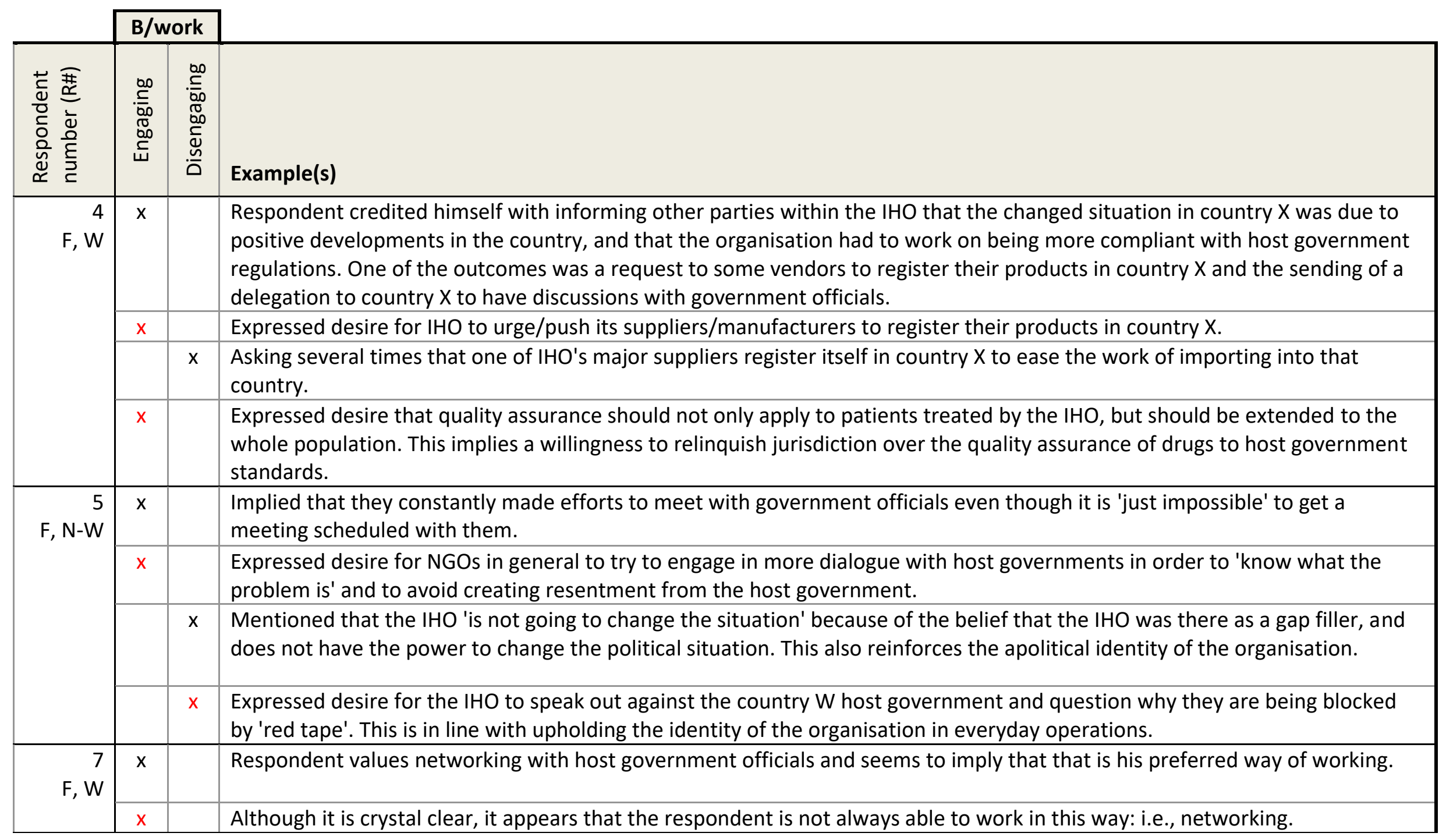


B/work

\begin{tabular}{|c|c|c|c|}
\hline 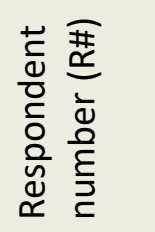 & 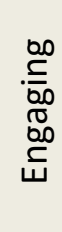 & 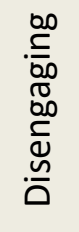 & Example(s) \\
\hline & & & $\begin{array}{l}\text { Does not believe in 'putting pressure' on the government of country } X \text { through other agencies, describes thinking this is } \\
\text { possible as an 'illusion'. This implies that the respondent is of the opinion that attempts by the IHO to pressurise governments } \\
\text { into allowing them to work unhindered is not effective, and rules it out as a means of dealing with host governments that are } \\
\text { not accommodating of humanitarian NGOs. }\end{array}$ \\
\hline \multirow{2}{*}{$\begin{array}{r}9 \\
F, W\end{array}$} & & $x$ & $\begin{array}{l}\text { Fighting for 'space' to conduct humanitarian work when the organisation is invited to intervene, an activity that is in line with } \\
\text { the organisation's 'reputation of not being very diplomatic when it comes to fighting for our space'. }\end{array}$ \\
\hline & $x$ & & $\begin{array}{l}\text { Expressed desire for the IHO to sometimes 'be a little modest or moderate' and accept that sometimes a host government } \\
\text { 'might have a valid opinion' and understand why a certain approach that the IHO wishes to follow might not work. This implies } \\
\text { a willingness to relinquish jurisdiction to host governments over certain matters and under certain circumstances. }\end{array}$ \\
\hline $\begin{array}{r}10 \\
F, N-W\end{array}$ & $x$ & & $\begin{array}{l}\text { Expressed desire that the IHO negotiate and accept certain conditions imposed/required by the host government. Also of the } \\
\text { opinion that the IHO simply has to comply with host government regulations. This implies relinquishing jurisdiction/control } \\
\text { over certain aspects related to the IHO's modus operandi. }\end{array}$ \\
\hline \multirow[t]{2}{*}{$\begin{array}{r}11 \\
F, W\end{array}$} & $x$ & & $\begin{array}{l}\text { Respondent always seeks to understand regulations and why they are in place. Actively engages with relevant authorities to } \\
\text { get relevant/necessary information. }\end{array}$ \\
\hline & $x$ & & $\begin{array}{l}\text { Respondent states that he has no problem with complying with regulations that are clear and 'protect the healthcare' of } \\
\text { beneficiaries. This implies a willingness to relinquish jurisdiction over acceptable standards and/or accepting certain } \\
\text { regulations imposed by a host government. This is however conditional. }\end{array}$ \\
\hline
\end{tabular}




\begin{tabular}{|c|c|c|c|}
\hline \multirow[b]{2}{*}{ 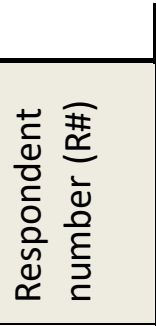 } & \multicolumn{2}{|c|}{ B/work } & \multirow[b]{2}{*}{ Example(s) } \\
\hline & 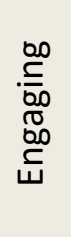 & 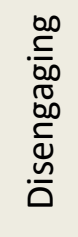 & \\
\hline & $\mathrm{x}$ & & $\begin{array}{l}\text { Although respondent has no problem complying with regulations, there was the implication that the choice was not always } \\
\text { entirely his own when he stated that 'but definitely there is an arrogance in the IHO as well'. In this case, he may wish to } \\
\text { comply, but this is beyond his control. }\end{array}$ \\
\hline $\begin{array}{r}13 \\
F, N-W\end{array}$ & $\mathrm{x}$ & & $\begin{array}{l}\text { Respondent does not seem to condone the general lack of consideration for the role of host governments by international } \\
\text { NGOs when intervening, implying a desire for NGOs to relinquish certain aspects of their modus operandi in order to avoid } \\
\text { situations where host governments, over time, refuse help from NGOs. }\end{array}$ \\
\hline \multirow{3}{*}{$\mathrm{HQ}, \mathrm{W}$} & $\mathrm{x}$ & & Involved local authorities in a project in the belief that this was the only way to get the job done. \\
\hline & & $\mathrm{x}$ & $\begin{array}{l}\text { Respondent believes that there is no country without legislation, and adheres to regulations even when he does not agree } \\
\text { with them. He gave an example of a standard in country } Z \text { that he felt was dangerous but he still accepted it because 'that is } \\
\text { the way they do it'. This implies relinquishing jurisdiction over ways of constructing/rehabilitating structures and adhering to } \\
\text { host government standards. }\end{array}$ \\
\hline & & $\mathrm{x}$ & $\begin{array}{l}\text { Expresses disapproval of the 'very high-level advocacy' approach of the IHO which entails bypassing the host government and } \\
\text { trying to get other parties involved in reversing host government decisions. This implies a desire to abandon this approach. }\end{array}$ \\
\hline $\begin{array}{r}17 \\
H Q, W \\
\end{array}$ & $\mathrm{x}$ & & $\begin{array}{l}\text { Respondent states that he spent 'years' trying to convince pharmacists to visit Country } X \text { and find out what was happening } \\
\text { and/or what could be done in the face of increasing difficulties in importing medicines. }\end{array}$ \\
\hline
\end{tabular}




\begin{tabular}{|c|c|c|c|}
\hline \multirow[b]{2}{*}{ 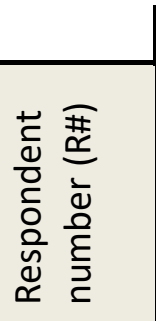 } & \multicolumn{2}{|c|}{ B/work } & \multirow[b]{2}{*}{ Example(s) } \\
\hline & 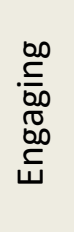 & 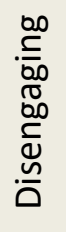 & \\
\hline & & $x$ & $\begin{array}{l}\text { States that that IHO does use unofficial channels to influence certain outcomes but does not offer bribes to parties that want } \\
\text { to be bribed in order to get things done. This implies reinforcement of the organisation's identity in everyday work. In } \\
\text { addition, although the respondent is not pleased with the conduct of the pharmacists regarding switching to using drugs } \\
\text { required by the host government, he supports the position that pharmacists have jurisdiction over quality by stating that 'it's } \\
\text { their problem' and demonstrates efforts to get them to do assessments in Country X. }\end{array}$ \\
\hline & & $x$ & $\begin{array}{l}\text { Expresses desire for the organisation to speak out, make clear statement and fight again human rights violations as part of its } \\
\text { identity. }\end{array}$ \\
\hline & & $x$ & $\begin{array}{l}\text { Expresses desire for the organisation to comply with regulations 'because it's their rules and they exist' and so the } \\
\text { organisation needs to cope with that. This implies a desire for the organisation to relinquish to the host government } \\
\text { jurisdiction over issues that are regulated in a country. }\end{array}$ \\
\hline \multirow[t]{2}{*}{$\begin{array}{r}21 \\
F, N-W\end{array}$} & $x$ & & $\begin{array}{l}\text { Respondent speaks of finding 'a way to help the patient but involving the host government authorities' as a way of responding } \\
\text { to regulations put in place by the host government. }\end{array}$ \\
\hline & & $x$ & $\begin{array}{l}\text { Expressed desire for the organisation to abandon its suspicious nature towards regulations and comply sooner for the benefit } \\
\text { of the affected population. This implies a willingness to relinquish jurisdiction over aspects regulated by the host government } \\
\text { for which the organisation has existing procedures for dealing with. }\end{array}$ \\
\hline $\begin{array}{r}22 \\
F, N-W\end{array}$ & $x$ & & $\begin{array}{l}\text { It can be deduced from the respondent's statements that is it not unusual for the organisation to engage in dialogue with the } \\
\text { host government on matters that affect the organisation's operations and/or when there is a conflict between what the host } \\
\text { government requires of the organisation and what the organisation wants to do. }\end{array}$ \\
\hline
\end{tabular}




\begin{tabular}{|c|c|c|c|}
\hline \multirow[b]{2}{*}{ 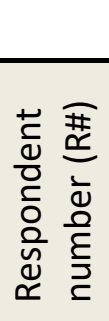 } & \multicolumn{2}{|c|}{ B/work } & \\
\hline & 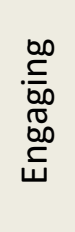 & 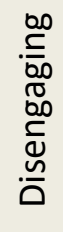 & Example(s) \\
\hline & & $x$ & $\begin{array}{l}\text { Expresses the need, and subsequent action, to make clear to the host government that the organisation does not get involved } \\
\text { in the politics of the situation because this makes 'life much simpler'. This reinforces the apolitical/neutral/impartial identity } \\
\text { of the organisation in its daily work. }\end{array}$ \\
\hline & & $x$ & $\begin{array}{l}\text { Expresses desire for the organisation to involve national staff in talks with host government authorities, which would be a } \\
\text { departure from the organisation's modus operandi. }\end{array}$ \\
\hline
\end{tabular}

